\title{
Intestinal mast cell tumour in a dog: Case report and review of current literature
}

\author{
Raida Al-Rukibat* and Zuhair Bani Ismail \\ Faculty of Veterinary Medicine, Jordan University of Science and Technology, P. O. Box 3030, Irbid 22110, Jordan
}

\begin{abstract}
Article history
Received: 26 Apr, 2016

Revised: 29 May, 2016

Accepted: 2 June, 2016

Abstract

A 7-years-old spayed, female Siberian Husky dog was diagnosed with malignant poorly differentiated intestinal mast cell tumour. The dog had previous history of colonic perforation which might have been associated with this malignant disease. The dog was presented with ascites which is uncommon sign of this disease. The disease was tentatively diagnosed by cytologic examination of the abdominal fluid and later confirmed histologically and by immunostaining.

Keywords: Mast cell tumour; dogs; miniature breeds
\end{abstract}

To cite this article: Al-Rukibat R and ZB Ismail, 2016. Intestinal mast cell tumour in a dog: Case report and review of current literature. Res. Opin. Anim. Vet. Sci., 6(4): 135-137.

\section{Introduction}

Mast cell tumour, one of the most common skin tumours in dogs, may also be found in visceral sites (mainly intestine, spleen and liver) (Iwata et al., 2000; Ozaki et al., 2002; Selting, 2007). Histopathological examination of tissue specimens is usually used to grade the tumour based on the degree of differentiation of the tumour cells (Takahashi et al., 2000; Misdorp, 2004). The staging of the tumour is clinical valuable to assist the surgeon in giving a more accurate prognosis and to provide a base-line data to which the surgeon can retrieve to evaluate therapeutic progress after initiation of therapy. The grading systems used to evaluate mast cell tumours are available in literature and can be summarized into 3 grades which are: undifferentiated or poorly differentiated, intermediately differentiated, and well-differentiated or mature according to the degree of cellularity, morphology of cancer cells and presence of mitotic figures (Takahashi et al., 2000; de Souza et al., 2001). Dogs that were diagnosed with grades 1 and 2 mast cell tumour have extremely poor survival rate after surgery (Grano et al., 2012). In this report, we describe an unusual case of poorly differentiated mast cell tumour originated from the intestine of a 7-years-old Siberian Husky dog. Although, the most common intestinal malignancy in dogs is lymphoma, in this case malignant mast cell tumour was suspected because some of the abnormal cells were found to contain sparsely scattered granules in their cytoplasm. A definitive diagnosis was then achieved by immunostaining using anti-tryptase antibodies.

\section{Case history and observations}

A 7-years-old spayed, female Siberian Husky dog was presented to the Veterinary Teaching Hospital with a history of decreased appetite, difficulty defecating and abdominal distension. The animal has had a previous surgery for a colonic perforation due to an unknown cause. At that time, colonic resection and anastomosis was performed and no other abnormalities were noted in the abdominal cavity. No further history was available regarding this previous illness. The dog had no previous history of cutaneous lesions. Samples were taken from abdominal mass and mesenteric lymph nodes and processed for histological and immuno-

*Corresponding author: Raida Al-Rukibat, Faculty of Veterinary Medicine, Jordan University of Science and Technology, P. O. Box 3030, Irbid 22110, Jordan; E-mail: ralrukib@ @ust.edu.jo 
histological techniques as described by Bancroft and Gamble (2001) and Kiupel et al. (2004) respectively.

\section{Results and Discussion}

On physical examination, the dog was lethargic; the abdominal cavity was moderately distended with fluid. Deep palpation of the abdomen could reveal multiple small masses. Abdominal ultrasound revealed several enlarged lymph nodes and a mass of mixed echogenicity. Abdominal fluid sample obtained by abdominocentesis and ultrasound-guided aspirate from the abdominal mass and mesenteric lymph nodes were submitted for cytological evaluation.

The cytological specimen of the abdominal fluid was of high cellularity and consisted primarily of eosinophils and mature non-degenerated neutrophils. The inflammatory cells were intermixed with low numbers of mononuclear cells which have round nuclei, a coarse to clumped chromatin pattern, occasionally prominent uneven multiple nucleoli, and scant to moderate amounts of deeply basophilic cytoplasm (Fig. 1). Many of these cells contained intracytoplasmic, small well-demarcated vacuoles. Few of these cells contained intracytoplasmic purple granules. Few red cells were present in the background. No etiologic agents were detected.

Cytological examination of tissue specimens obtained from the abdominal mass and mesenteric lymph nodes revealed good cellularity and consisted of individual large cells with increased numbers of nondegenerate neutrophils and eosinophils. The large cells contained round to oval nuclei, a coarse to clumped chromatin pattern, occasionally large prominent multiple irregular nucleoli, and scant to moderate amounts of basophilic cytoplasm which were variably vacuolated. Multinucleated cells were occasionally seen and mitotic figures were infrequently found. A few of these cells appeared to have expansible cytoplasm which contained low numbers of metachromatic granules. Anisocytosis and anisockaryosis were moderate. In the mesenteric lymph nodes, there was low cellularity which consisted mainly of a mixed population of neoplastic and inflammatory cells. Based on the findings of the abdominal fluid and the abdominal mass cytological examination, a malignant neoplastic process intermixed with an eosinophilic neutrophilc inflammatory reaction was suspected. The presence of the large mononuclear cells in the abdominal fluid was particularly concerning. Since these large cells have a lymphoid appearance, lymphoma was placed high in the differential diagnosis. However, because some of the cells also appeared to contain intracytoplasmic purple granules, poorly differentiated mast cell tumour could not be ruled out at this stage and surgical biopsy was recommended for further diagnostic evaluation.

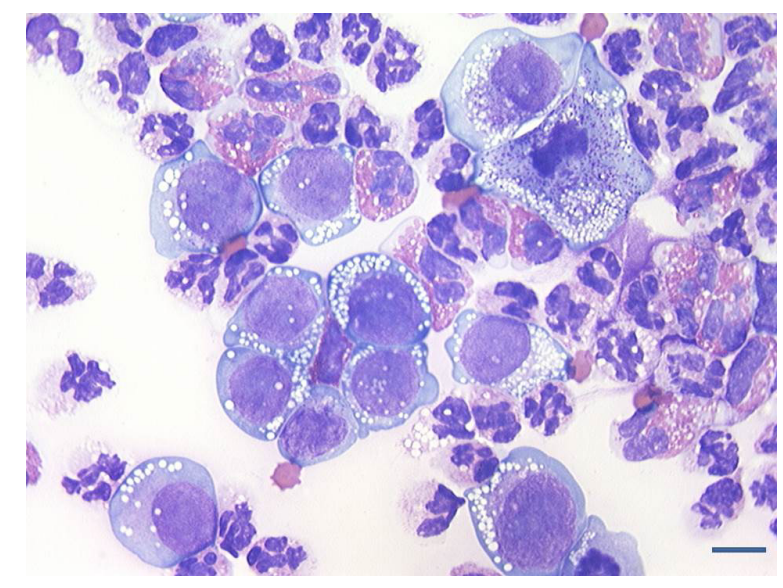

Fig. 1: Wright's stained specimen of abdominal fluid from a 7-years-old spayed, female Siberian Husky dog presented with abdominal distension. The specimen was characterized by high cellularity and consisted primarily of eosinophils and mature nondegenerated neutrophils. The inflammatory cells were intermixed with low numbers of mononuclear cells which have round nuclei, a coarse to clumped chromatin pattern, occasionally prominent uneven multiple nucleoli, and scant to moderate amounts of deeply basophilic cytoplasm. Many of these cells contained intracytoplasmic, small well-demarcated vacuoles. Few of them contained intracytoplasmic purple granules. $\mathrm{Bar}=\mathbf{1 0} \boldsymbol{\mu m}$.

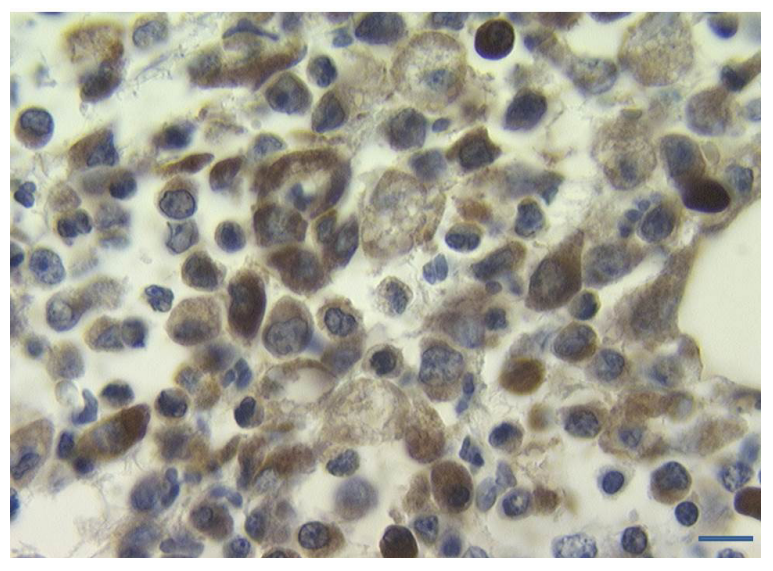

Fig. 2: Positive immunostaining of mast cell tryptase taken from an intestinal tumour mass originating from the wall of the colon in a 7-year-old spayed, female Siberian Husky dog presented with abdominal distension. Bar $=10 \mu \mathrm{m}$.

Because of the poor prognostic projection of the case, the owner elected to euthanatize the dog and a complete necropsy was performed. In the abdominal cavity, there was approximately $500 \mathrm{ml}$ of pale red fluid and multiple adhesions between the omentum and the abdominal wall. A large irregular, firm, tan-coloured mass $(8 \mathrm{~cm}$ in diameter $)$ was found attached to the 
Table 1: A review of the signalmnet, origin and presenting clinical signs of canine visceral mast cell tumours in the last 15

\begin{tabular}{|c|c|c|c|c|}
\hline Reference & $\begin{array}{c}\text { Number of } \\
\text { cases }\end{array}$ & Signalment & Location & Presenting clinical signs \\
\hline $\begin{array}{l}\text { Takahashi et al., } \\
2000\end{array}$ & 10 & $\begin{array}{l}\text { Adult purebred male dogs } \\
\text { of miniature breed dogs }\end{array}$ & $\begin{array}{l}\text { Gastrointestinal tract, spleen, } \\
\text { liver }\end{array}$ & $\begin{array}{l}\text { Anorexia, lethargy, } \\
\text { vomiting, and diarrhea, } \\
\text { anemia, hypoproteinemia, } \\
\text { mastocythemia }\end{array}$ \\
\hline $\begin{array}{l}\text { de Souza et al., } \\
2001\end{array}$ & 1 & 8 years old Siberian Husky & Visceral & $\begin{array}{l}\text { Peritoneal effusion } \\
\text { Skin lesions }\end{array}$ \\
\hline Ozaki et al., 2002 & 39 & $\begin{array}{l}\text { Miniature breeds, } \\
\text { especially Maltese, } \\
\text { Average age } 9.7 \text { years }\end{array}$ & $\begin{array}{l}\text { Stomach, duodenum, small } \\
\text { intestine, and large intestine } \\
\text { and in multiple areas }\end{array}$ & $\begin{array}{l}\text { Vomiting, diarrhea, and } \\
\text { melena }\end{array}$ \\
\hline $\begin{array}{l}\text { Grano et al., } \\
2012\end{array}$ & 1 & $\begin{array}{l}6 \text { years old German } \\
\text { shepherd }\end{array}$ & $\begin{array}{l}\text { Thymus, medenteric and } \\
\text { abdominal lymph nodes }\end{array}$ & $\begin{array}{l}\text { Anorexia, hematomesis, } \\
\text { diarrhea }\end{array}$ \\
\hline
\end{tabular}

small colon. Another mass $(10 \mathrm{~cm}$ in diameter) was attached to the jejunum with multiple adhesions to the omentum. Scattered smaller masses (up to $3 \mathrm{~cm}$ in diameter) were also found attached to the serosal surface of the small and large intestine. Tissue specimens from the colonic mass as well as from other masses were submitted in $4 \%$ buffered formalin solution for histopathological examination. In the colonic mass, there were sheets of round cells with round to oval nuclei, occasionally prominent multiple nucleoli, and scant to moderate amounts of deeply basophilic cytoplasm. Small vacuoles were present within the cytoplasm along with occasional granules. Anisocytosis and anisokaryosis were moderate. Multinucleated cells were occasionally seen and mitotic figures were found infrequently. In the mass associated with the jejunum, there were few cells that appeared to have expansible cytoplasm that contained a few small granules. Numerous eosinophils were intermingled with the tumour cells and a lesser number of neutrophils were seen. Some of the blood vessels contained thrombi. A poorly demarcated nodule composed of a similar population of neoplastic and inflammatory cells was present in the serosa of the colon and extended to the adjacent mesentery.

Based on the findings of the histolpathological examination, the diagnosis of undifferentiated sarcoma was suspected. However, immunohistochemical examination of the paraffin-embedded tissues demonstrated that the majority of the tumour cells were strongly positive for mast cell tryptase (Fig. 2). They were unreactive with a broad spectrum of antibodies against $\mathrm{B}$ and $\mathrm{T}$ lymphocytes, smooth muscle alpha actin and cytokeratin. The mast cell nature of this tumour was best identifiable by immunostaining for mast cell tryptase and a final diagnosis was made as undifferentiated mast cell tumour.

A review of the signalment, origin and presenting clinical signs of canine visceral mast cell tumours in the last 15 years are presented in Table 1 . When a visceral mast cell tumour is present, neoplastic mast cells may be found in any effusion secondary to the tumour (Misdorp et al., 2004). Therefore, a tentative diagnosis may be made by cytologic analysis of the effusion. However, usually further evaluation is deemed necessary to confirm the diagnosis and more importantly to stage the progress of the disease.

\section{References}

Bancroft JD, Gamble M (2001) Theory and Practice of Histological Techniques, 5th Edition. Churchill Livingstone.

de Souza ML, Torres LF, Rocha NS, Takahira RK, Mamprim MJ, Burini CHP, Bandarra EP, Figueiredo LM (2001) Peritoneal Effusion in a Dog Secondary to Visceral Mast Cell Tumour. Acta Cytologica, 45: 89-92.

Grano F, Silva JES, Melo GD, Schweigert A, Ciarlini PC, Machado GF (2012). Visceral mast cell tumour and mastocythaemia in dog. Braz J Vet Pathol, 5: 142-145.

Iwata $\mathrm{N}$, Ochiai $\mathrm{K}$, Kadosawa $\mathrm{T}$, Takiguchi $\mathrm{M}$, Umemura T (2000) Canine extracutaneous mastcell tumours consisting of connective tissue mast cells. J Comp Path, 4: 306-10.

Kiupel M, Webster JD, Kaneene JB, Miller R, Yuzbasiyan-Gurkan V (2004) The use of KIT and tryptase expression patterns as prognostic tools for canine cutaneous mast cell tumors. Vet Pathol 41: 371-377.

Misdorp W (2004) Mast cells and canine mast cell tumours. A review. Vet Quart, 26: 156-169.

Ozaki K, Yamagani K, Nomura K, Narama I (2002) Mast cell tumours of the gastrointestinal tract in 39 dogs. Vet Pathol, 39: 557-564.

Selting KA (2007) In: Withrow and McEwen's Small animal clinical oncology, 4th edition, Philadelphia. WB Saunders, 491-503.

Takahashi T, Kadosawa T, Nagase M, Matsunaga S, Mochizuki M, Nishimura R, Sasaki N (2000) Visceral mast cell tumours in dogs: 10 cases (1982-1997). J Am Vet Med Assoc, 216: 222-226. 